\title{
Purification, Properties and Regulation of Glutamine Synthetase from Nitrobacter agilis
}

\author{
By SHARAD KUMAR AND D. J. D. NICHOLAS* \\ Department of Agricultural Biochemistry, Waite Agricultural Research Institute, University of \\ Adelaide, Glen Osmond 5064, South Australia
}

(Received 6 May 1983; revised 15 September 1983)

\begin{abstract}
Glutamine synthetase (EC 6.3.1.2) was purified about 430 -fold from the nitrifying bacterium Nitrobacter agilis by affinity chromatography on Blue Sepharose CL-6B and gel filtration on Sepharose 4B. The enzyme (apparent mol. wt 700000), which consisted of 12 subunits, each of mol. wt 58000, required a divalent cation for both biosynthetic and transferase activities. Regulation of glutamine synthetase both by a feedback inhibition involving amino acids and by an adenylylation/deadenylylation mechanism was studied. The enzyme was highly adenylylated $(75-90 \%)$ in cell free extracts from cells grown on nitrite as the sole source of nitrogen. The adenylylated form of the enzyme could be deadenylylated by treatment with snake venom phosphodiesterase. An isoactivity $\mathrm{pH}$ of 7.4 was recorded for glutamine synthetase.
\end{abstract}

\section{INTRODUCTION}

Glutamine synthetase [EC 6.3.1.2; L-glutamate :ammonia ligase (ADP forming)] is one of the key enzymes for ammonia assimilation in a variety of bacteria and has been the subject of several reviews (Shapiro \& Stadtman, 1970; Meister, 1974; Tyler, 1978). The enzyme from Escherichia coli is regulated by a complex set of mechanisms (Magasanik et al., 1974) involving feedback inhibition, repression and adenylylation/deadenylylation (Woolfolk et al., 1966; Ginsburg \& Stadtman, 1973; Wohlhueter et al., 1973). In recent years, the properties of glutamine synthetase have been studied in a variety of bacteria (Bender et al., 1977; Siedel \& Shelton, 1979; Alef et al., 1981; Alef \& Zumft, 1981; Bhandari \& Nicholas, 1981; Khanna \& Nicholas, 1983). In general, glutamine synthetase from Gram-negative bacteria is regulated by an adenylylation/deadenylylation mechanism (Ginsburg \& Stadtman, 1973). The unadenylylated form (GS) and the adenylylated form (GS-AMP) of the enzyme differ in their regulatory properties (Bender et al., 1977; Alef \& Zumft, 1981). It is well known that the adenylylation state of the enzyme depends on the nitrogen source in the growth medium. Thus, cells grown with $\mathrm{NH}_{4}^{+}$contain glutamine synthetase largely in an adenylylated form (Wohlheuter et al., 1973). The chemolithotrophic nitrifying bacteria usually rely on a specific nitrogen source for their nitrogen and energy requirements; for example Nitrobacter and Nitrosomonas utilize $\mathrm{NO}_{2}^{-}$and $\mathrm{NH}_{4}^{+}$respectively. Although glutamine synthetase from Nitrosomonas europaea has been purified and some of its properties studied (Bhandari \& Nicholas, 1981), little is known about its role in Nitrobacter agilis. Aspects of the metabolism of nitrifying bacteria have been reviewed on several occasions (Aleem, 1970, 1977; Kelly, 1971; Nicholas, 1963, 1978; Suzuki, 1974; Wallace $\&$ Nicholas, 1969). We now report on the purification, properties and regulation of glutamine synthetase from $N$. agilis.

Abbreviations: CTAB, cetyltrimethylammonium bromide; SVP, snake venom phosphodiesterase. 


\section{METHODS}

Bacteria and growth conditions. Batch cultures (40 1) of Nitrobacter agilis ATCC 14123 were grown at $28^{\circ} \mathrm{C}$ for $5 \mathrm{~d}$ in an inorganic medium (Wallace et al., 1969) and harvested by continuous flow centrifugation (Sorvall) at $4{ }^{\circ} \mathrm{C}$ as described previously (Bhandari \& Nicholas, 1979; Kumar \& Nicholas, 1981). Harvested cells, washed several times with cold $10 \mathrm{mM}$-Tris/ $\mathrm{HCl}, 1 \mathrm{~mm}-\mathrm{MnCl}_{2}$ buffer $(\mathrm{pH} 7 \cdot 2)$ were finally suspended in an appropriate volume of the same buffer.

Preparation of cell extracts. Washed cells in $10 \mathrm{mM}-\mathrm{Tris} / \mathrm{HCl}, 1 \mathrm{mM}-\mathrm{MnCl}_{2}$ buffer $(\mathrm{pH} 7 \cdot 2)$ were disrupted with an ultrasonic probe $\left(20 \mathrm{kHz}\right.$ ) with $2 \mathrm{~min}$ bursts over a period of $30 \mathrm{~min}$ at $4{ }^{\circ} \mathrm{C}$ in an ice bath. Sonicated extracts were centrifuged at $30000 \mathrm{~g}$ for $20 \mathrm{~min}$ at $4{ }^{\circ} \mathrm{C}$. The supernatant $\left(\mathrm{S}_{30}\right)$ was used for the purification of glutamine synthetase.

Purification of glutamine synthetase. The $\mathrm{S}_{30}$ fraction was heat-treated at $50^{\circ} \mathrm{C}$ for $15 \mathrm{~min}$ with constant stirring, then chilled in ice for $15 \mathrm{~min}$ and centrifuged at $30000 \mathrm{~g}$ for $15 \mathrm{~min}$. The supernatant contained all the glutamine synthetase activity. Longer heat treatment or higher temperatures resulted in a loss of enzyme activity. The supernatant was loaded onto a Blue Sepharose CL-6B column $(1.5 \times 9 \mathrm{~cm})$ equilibrated against $10 \mathrm{mM}-\mathrm{Tris} / \mathrm{HCl}$,

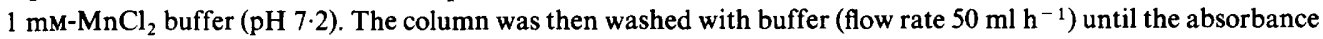
$\left(A_{280}\right)$ was close to zero. Glutamine synthetase was eluted from the column with 2 mM-ADP in the same buffer. Active fractions were pooled, dialysed against buffer overnight, concentrated on an Amicon PM-10 membrane and loaded onto a Sepharose $4 \mathrm{~B}$ column $(2 \times 70 \mathrm{~cm})$ equilibrated against the buffer. The enzyme was eluted with the same buffer (flow rate $12 \mathrm{ml} \mathrm{h}^{-1}$ ) and the active fractions pooled and concentrated as before.

Polyacrylamide gel electrophoresis. This was carried out in 5 and $7 \%(\mathrm{w} / \mathrm{v})$ polyacrylamide tube gels. The stacking gel was $3 \%(\mathrm{w} / \mathrm{v})$ polyacrylamide in $125 \mathrm{~mm}$ - Tris $/ \mathrm{HCl}$ buffer $(\mathrm{pH} 6.8)$ and the running gel 5 or $7 \%(\mathrm{w} / \mathrm{v})$ polyacrylamide in $375 \mathrm{~mm}$-Tris/ $\mathrm{HCl}$ buffer ( $\mathrm{pH} \mathrm{8.8)}$ ). The electrode buffer was $12.5 \mathrm{~mm}$-Tris, $96 \mathrm{~mm}$-glycine (pH 8.4). Electrophoresis was carried out at $2 \mathrm{~mA}$ per gel at constant current. Gels were stained with Coomassie brilliant blue R250.

Determination of molecular weight. The molecular weight of the native enzyme was determined by gel filtration in a Sepharose $6 \mathrm{~B}$ column $(1.6 \times 100 \mathrm{~cm})$ equilibrated with $50 \mathrm{mM}$-Tris/HCl buffer $(\mathrm{pH} 7.5)$ according to the method of Andrews (1970). The column was calibrated with aldolase $\left(M_{\mathrm{r}} 158000\right)$, catalase $\left(M_{\mathrm{r}} 232000\right)$, ferritin $\left(M_{\mathrm{r}} 440000\right)$ and thryoglobulin $\left(M_{\mathrm{r}} 669000\right)$ as marker proteins. The determination of subunit molecular weight was done by discontinuous gel electrophoresis in the presence of $0 \cdot 1 \%(\mathrm{w} / \mathrm{v})$ SDS using Tris/glycine buffer (pH $8 \cdot 3$ ) according to the methods of Laemmli (1970) and Weber \& Osborn (1975). The gels were calibrated with the following protein standards: phosphorylase $b\left(M_{\mathrm{r}} 94000\right)$, albumin $\left(M_{\mathrm{r}} 67000\right)$, ovalbumin $\left(M_{\mathrm{r}} 43000\right)$, carbonic anhydrase $\left(M_{\mathrm{r}} 30000\right)$ and trypsin inhibitor $\left(M_{\mathrm{r}} 20100\right)$.

Enzyme assays. Both the $\gamma$-glutamyl transferase and the biosynthetic activities of glutamine synthetase were determined by the methods of Shapiro \& Stadtman (1970). The reaction mixture in a final volume of $1 \mathrm{ml}$ contained (mM): imidazole/ $\mathrm{HCl}(\mathrm{pH} 7.2$ or 7.4$), 40$; glutamine, 30; hydroxylamine hydrochloride (neutralized with $2 \mathrm{M}-\mathrm{NaOH}), 30 ; \mathrm{MnCl}_{2} .4 \mathrm{H}_{2} \mathrm{O}, 0.5$; sodium arsenate, 20 ; ADP, $0 \cdot 4$; and an appropriate quantity of enzyme. For the in vivo assay in whole cells, the assay mixture also contained $20 \mu \mathrm{g}$ cetyltrimethylammonium bromide (CTAB) $\mathrm{ml}^{-1}$. Control tubes without glutamine and hydroxylamine, respectively, were always included. For bio-

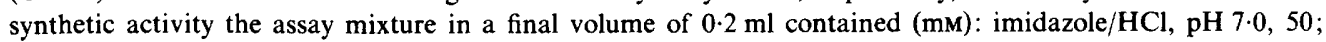
glutamate, $100 ; \mathrm{NH}_{4} \mathrm{Cl}, 50 ; \mathrm{ATP}, 10 ; \mathrm{MgCl}_{2}, 5$ and an appropriate quantity of enzyme. Glutamate was omitted from control tubes and a correction was also made for non-enzymic production of $P_{i}$ from ATP. All incubations were at $37^{\circ} \mathrm{C}$, usually for $15-30 \mathrm{~min}$.

Protein and ammonia determinations. Protein was determined by the method of Bradford (1976) using bovine serum albumin as a standard. Ammonia was assayed by the method of Ballantine (1957) using $\mathrm{NH}_{4} \mathrm{Cl}$ as a standard.

Biochemicals. AMP, ADP, ATP, imidazole, $\gamma$-glutamyl hydroxamate $(\gamma \mathrm{GH})$, snake venom phosphodiesterase (SVP) and various amino acids were purchased from Sigma. Molecular weight standards were from Pharmacia. All other chemicals were the best grade available. Double glass-distilled water was used throughout.

Chromatographic material. Blue Sepharose CL-6B, Sepharose 4B and Sepharose 6B were purchased from Pharmacia and were prepared for use according to the instructions from the manufacturer.

\section{RESULTS}

\section{Purification and properties of glutamine synthetase}

Glutamine synthetase was purified about 430 -fold by affinity chromatography on Blue Sepharose CL-6B and gel filtration on Sepharose 4B (Table 1). The purified enzyme had a specific activity of $220 \mu \mathrm{mol} \gamma$-glutamyl hydroxamate produced $\min ^{-1}$ (mg protein) ${ }^{-1}$ and moved as a single major band in polyacrylamide gel electrophoresis under both denaturing and 
Table 1. Purification of glutamine synthetase

All purification steps (except heat treatment) were performed at $4{ }^{\circ} \mathrm{C}$ as described in Methods. Enzyme activity was determined by following the production of $\gamma$-glutamyl hydroxamate from L-glutamine and $\mathrm{NH}_{2} \mathrm{OH}$ at $\mathrm{pH} 7 \cdot 2$. One enzyme unit is defined as $\mu$ mol $\gamma$-glutamyl hydroxamate produced $\min ^{-1}$ and specific activity as number of units (mg protein) ${ }^{-1}$.

\begin{tabular}{lccrrr}
\multicolumn{1}{c}{$\begin{array}{c}\text { Purification } \\
\text { step }\end{array}$} & $\begin{array}{c}\text { Total } \\
\text { protein } \\
(\mathrm{mg})\end{array}$ & $\begin{array}{l}\text { Total } \\
\text { units }\end{array}$ & $\begin{array}{c}\text { Specific } \\
\text { activity }\end{array}$ & $\begin{array}{c}\text { Purification } \\
\text { (fold) }\end{array}$ & $\begin{array}{c}\text { Recovery } \\
(\%)\end{array}$ \\
Crude extract $\left(\mathrm{S}_{30}\right)$ & $148 \cdot 56$ & $75 \cdot 81$ & $0 \cdot 51$ & $1 \cdot 0$ & 100 \\
Heat treatment & $100 \cdot 81$ & 69.92 & $0 \cdot 69$ & $1 \cdot 4$ & 94 \\
Pooled Blue Sepharose CL-6B fractions & $2 \cdot 10$ & $45 \cdot 33$ & $21 \cdot 59$ & $42 \cdot 3$ & 60 \\
Pooled Sepharose 4B fractions & $\mathbf{0 . 2 0}$ & $\mathbf{4 4 . 0}$ & $220 \cdot 0$ & $431 \cdot 0$ & 58
\end{tabular}

\section{Table 2. Effect of $\mathrm{NH}_{4}^{+}$on $\mathrm{K}_{\mathrm{m}}$ of the substrates of $\gamma$-glutamyl transferase activity of purified glutamine synthetase}

Transferase activity of the enzyme was measured as described in Methods except that the amounts of glutamine and $\mathrm{NH}_{2} \mathrm{OH}$ were varied between 0 and $50 \mathrm{mM}$ and $\mathrm{NH}_{4} \mathrm{Cl}$ was included in the assay mixture as indicated. $K_{\mathrm{m}}$ values were determined from double reciprocal plots of rates of reaction against the initial substrate concentration according to Lineweaver and Burk. The data were analysed by a computer program (Cleland, 1967); SEM values are shown.

$\begin{array}{ccc}\begin{array}{c}\mathrm{NH}_{4}^{+} \text {concn } \\ (\mathrm{mM})\end{array} & \overbrace{\text { Glutamine }}^{K_{\mathrm{m}}(\mathrm{mM})} & \mathrm{NH}_{2} \mathrm{OH} \\ 0 & 11 \cdot 6 \pm 1 \cdot 5 & 2 \cdot 6 \pm 0 \cdot 8 \\ 10 & 18 \cdot 2 \pm 1 \cdot 6 & 4 \cdot 0 \pm 0 \cdot 3 \\ 20 & 23 \cdot 8 \pm 2 \cdot 1 & 5 \cdot 1 \pm 0 \cdot 1 \\ 30 & 27 \cdot 8 \pm 1 \cdot 0 & 5 \cdot 6 \pm 0 \cdot 1\end{array}$

non-denaturing conditions. The purified enzyme was stable for several weeks at $-10^{\circ} \mathrm{C}$. The approximate molecular weight of the enzyme was 700000 , while the subunit molecular weight determined in SDS gels was 58000, indicating that the enzyme is composed of 12 homologous subunits. The $K_{\mathrm{m}}$ values for the substrates of the glutamyl transferase reaction, glutamine and $\mathrm{NH}_{2} \mathrm{OH}$, were $11.6 \mathrm{mM} \pm 1.5(\mathrm{SEM})$ and $2.6 \mathrm{mM} \pm 0.8$, respectively; and for the substrates of biosynthetic reaction, glutamate and $\mathrm{NH}_{4}^{+}$, were $6.3 \pm 1.6$ and $0.2 \mathrm{~mm}$ respectively. Ammonia competitively inhibited the transferase reaction and it decreased the affinity of the enzyme for both glutamine and $\mathrm{NH}_{2} \mathrm{OH}$ (Table 2). Both the transferase and the biosynthetic activities required a divalent cation. Maximum transferase activity was recorded with $\mathrm{Mn}^{2+}(0 \cdot 3-10 \mathrm{mM})$ and the order of effectiveness of the divalent cations (at $10 \mathrm{mM}$ ) was $\mathrm{Mn}^{2+}>\mathrm{Cu}^{2+}>\mathrm{Mg}^{2+}>$ $\mathrm{Co}^{2+}$; for biosynthetic activity it was $\mathrm{Mg}^{2+}>\mathrm{Mn}^{2+}>\mathrm{Zn}^{2+} \mathrm{Cu}^{2+}>\mathrm{Ni}^{2+}$.

\section{Feedback inhibition}

Feedback inhibition of glutamine synthetase by various amino acids and nucleotides has been reported in many bacteria, e.g. Escherichia coli (Kingdon \& Stadtman, 1967), Bacillus licheniformis (Hubbard \& Stadtman, 1967), Klebsiella aerogenes (Bender et al., 1977), Rhodopseudomonas capsulata (Johansson \& Gest, 1976), Nitrosomonas europaea (Bhandari \& Nicholas, 1981), Chlorobium vibrioforme (Khanna \& Nicholas, 1983) and Methylcocccus capsulatus (Murrell $\&$ Dalton, 1983). The purified enzyme from Nitrobacter agilis was similarly inhibited. Thus at $10 \mathrm{~mm}$ final concentration, alanine, serine, glycine and tryptophan inhibited transferase activity by $65,45,40$ and $33 \%$, and biosynthetic activity by $60,30,35$ and $5 \%$, respectively. When the inhibition data were plotted as double reciprocal plots of the fractional inhibition against the concentration of amino acids, the values of the intercepts on the $y$ axes were $>1$, indicating that these amino acids only partially inhibited the enzyme activity at saturating concentrations. The combined effects of various amino acids on the transferase activity are shown in Table 3 . The inhibition due to various combinations of amino acids was cumulative rather than additive, 
Table 3. Feedback inhibition of purified glutamine synthetase by amino acids

Transferase activity of the enzyme was determined as described in Methods except that the reaction mixture also contained $5 \mathrm{mM}$ of the appropriate amino acid, as indicated. Values for cumulative inhibition were calculated according to the method of Stadtman et al. (1968).

\begin{tabular}{lccc} 
& \multicolumn{3}{c}{ Percentage inhibition } \\
\cline { 2 - 4 } Amino acid(s) & Observed & Cumulative & Additive \\
Ala & 40 & - & - \\
Gly & 27 & - & - \\
Ser & 36 & - & - \\
Ala + Gly & 52 & 56 & 67 \\
Ala + Ser & 62 & 62 & 76 \\
Ser + Gly & 52 & 53 & 63 \\
Ala + Gly + Ser & 69 & 72 & 103
\end{tabular}

Table 4. Effects of CTAB treatment on transferase activity in cell suspensions and in cell-free extracts $\left(S_{25}\right)$

Exponentially growing cultures (1 l) were harvested in $250 \mathrm{ml}$ polycarbonate bottles in a Sorvall-GSA rotor at $10000 \mathrm{~g}$ for $20 \mathrm{~min}$ at $4^{\circ} \mathrm{C}$. As indicated, CTAB was added to cultures $\left(2.5 \mu \mathrm{g} \mathrm{ml}^{-1}\right)$ before harvesting. Cells washed once with cold $10 \mathrm{mM}$-Tris/ $\mathrm{HCl}, 1 \mathrm{mM}-\mathrm{MnCl}_{2}$ buffer $(\mathrm{pH} 7 \cdot 2)$ were finally suspended in a small volume (approx. $5 \mathrm{ml}$ ) of the buffer. For in vitro assay, cell suspensions were sonicated for $20 \mathrm{~min}$ and then centrifuged at $25000 \mathrm{~g}$ for $15 \mathrm{~min}$. The supernatant $\left(\mathrm{S}_{25}\right)$ and cell suspension were used to determine the transferase activity at $\mathrm{pH} 7.4$ with and without $60 \mathrm{mM}-\mathrm{MgCl}_{2}$, as described in Methods. Transferase activity is defined as $\mu \mathrm{mol} \gamma$-glutamyl hydroxamate produced $(30 \mathrm{~min})^{-1}(\mathrm{mg} \text { protein })^{-1}$.

$\begin{array}{lcccc}\text { Assay } & \begin{array}{c}\text { CTAB } \\ \text { treatment }\end{array} & \overbrace{-\mathrm{Mg}^{2+}}^{\text {Transferase activity }}+\mathbf{M g}^{2+} & \begin{array}{c}\mathrm{Mg}^{2+} /-\mathrm{Mg}^{2+} \\ \text { ratio }\end{array} \\ \text { in vitro } & - & 10 \cdot 50 & 2 \cdot 10 & 0 \cdot 20 \\ & + & 9 \cdot 30 & 1 \cdot 50 & 0 \cdot 16 \\ \text { in vivo } & - & 13 \cdot 50 & 2 \cdot 25 & 0 \cdot 17 \\ & + & 12.50 & 3 \cdot 0 & 0 \cdot 23\end{array}$

indicating that each modifier is completely independent in its action and thus it is possible that separate binding sites on the enzyme are present for each of the inhibitors, as proposed for the $E$. coli enzyme (Stadtman et al., 1968).

\section{Adenylylation/deadenylylation}

In enteric bacteria (Stadtman et al., 1970; Bender et al., 1977), photosynthetic bacteria (Johansson \& Gest, 1977; Alef \& Zumft, 1981; Michalski et al., 1983) and rhizobia (Darrow \& Knotts, 1977) the extent of transferase activity in the presence of $60 \mathrm{mM}-\mathrm{MgCl}_{2}$ has been used as an indication of the degree of adenylylation of glutamine synthetase. The fully adenylylated enzyme is inactive in the presence of $\mathbf{M g}^{2+}$, whereas the deadenylylated enzyme is not affected. Since the adenylylation state of the enzyme can change during harvesting of the bacteria (Bender et al., 1977) CTAB was added to cultures to stabilize the adenylylation state of the enzyme. The data in Table 4 indicate that the enzyme from normally grown $N$. agilis cells was severely inhibited by $\mathrm{Mg}^{2+}$. The CTAB treatment of $N$. agilis cells prior to harvest had little effect on the extent of $\mathrm{Mg}^{2+}$ inhibition of transferase activity. Similar results were observed when cells harvested with or without $\mathrm{CTAB}$ were assayed for in vivo transferase activity. Based on a 12 subunit enzyme and applying the Shapiro \& Stadtman (1970) formula $\left[E_{\mathrm{n}}^{-}=12-12\left(+\mathrm{Mg}^{2+} /-\mathrm{Mg}^{2+}\right)\right]$, an adenylylation state of 9 can be calculated for the $N$. agilis enzyme, and it varied between 8 and 11 in 20 separately grown batches of cells.

The effects of SVP treatment on transferase activity of glutamine synthetase, with and without $60 \mathrm{mM}-\mathrm{MgCl}_{2}$, are shown in Fig. 1. In these experiments, transferase assays were carried out 


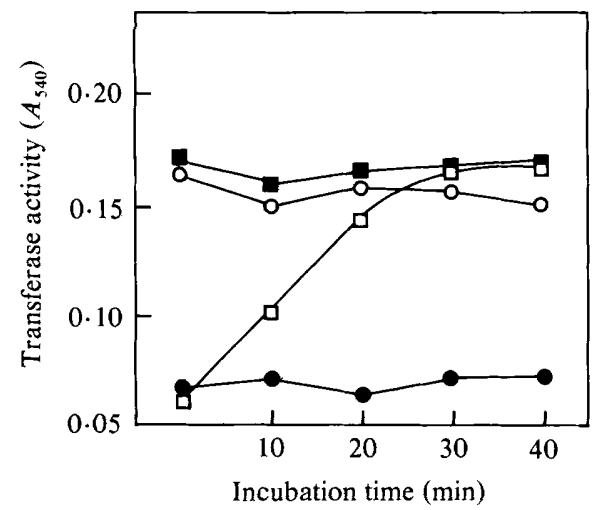

Fig. 1

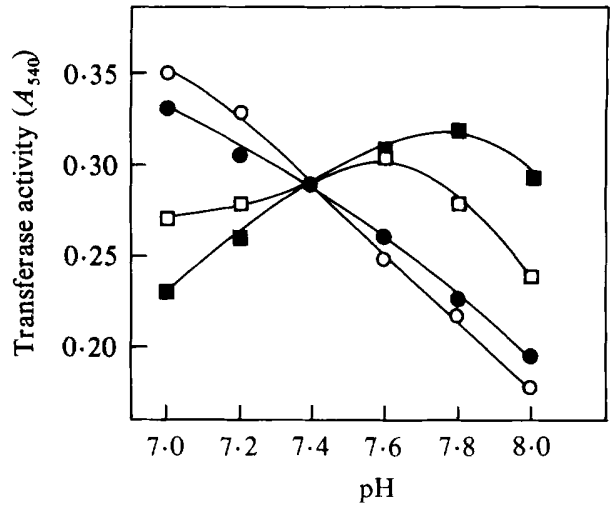

Fig. 2

Fig. 1. Effects of SVP treatment on purified glutamine synthetase. The pH of a sample of purified enzyme was adjusted to 8.8 with $1 \mathrm{M}$-Tris and then divided into two equal volumes. One was treated with SVP $\left(50 \mu \mathrm{g} \mathrm{ml}^{-1}\right)$ at $37^{\circ} \mathrm{C}$ and the other used as a control. At the times indicated, samples of untreated and SVP-treated enzyme were withdrawn and assayed for transferase activity with and without $60 \mathrm{mM}-\mathrm{MgCl}_{2}$ at $\mathrm{pH} 7.4$. Enzyme activity is expressed as $A_{540}$. The enzyme preparation was diluted initially so that $50 \mu \mathrm{l}$ of enzyme produced enough $\gamma$-glutamyl hydroxamate in 15 min to give an absorbance of about $0 \cdot 15$ (without added $\mathrm{Mg}^{2+}$ ). Untreated enzyme with (O) and without (O) $\mathrm{Mg}^{2+}$; treated enzyme with ( $\square$ ) and without $(\square) \mathrm{Mg}^{2+}$.

Fig. 2. Determination of the isoactivity $\mathrm{pH}$ of purified glutamine synthetase. SVP-treatment $\left(20 \mu \mathrm{g} \mathrm{ml}^{-1}\right)$ of purified enzyme was as described in Fig. 1. The transferase activity of treated and untreated preparations was determined at various $\mathrm{pH}$ values as described in Methods. Untreated glutamine synthetase (O), SVP-treated for $20 \mathrm{~min}(\bigcirc), 40 \mathrm{~min}(\square)$ and $60 \mathrm{~min}(\square)$, respectively.

at $\mathrm{pH} 7.4$ in the presence of $0.3 \mathrm{mM}-\mathrm{MnCl}_{2}$. The $\mathrm{Mg}^{2+}$ inhibition of transferase activity of purified glutamine synthetase was completely reversed after a $30 \mathrm{~min}$ treatment with SVP.

The adenylylated and unadenylylated forms of glutamine synthetase have different $\mathrm{pH}$ optima for transferase activity; the adenylylated form has a lower $\mathrm{pH}$ optimum (Bender et al., 1977). By treating glutamine synthetase from $N$. agilis with SVP for defined periods, it was possible to prepare the enzyme at various stages of adenylylation as shown in Fig. 2. The native enzyme (without SVP treatment) had a pH optimum of around 7.0 and the deadenylylated form (SVP-treated for $60 \mathrm{~min}$ ) at 7.8. The isoactivity point of the two forms of the enzyme was about 7.4 and this explains why the transferase activity of the enzyme was not affected by SVP treatment when assayed in the absence of $\mathrm{Mg}^{2+}$ (Fig. 1).

The two forms of enzyme have been shown to be inhibited differentially by feedback inhibitors (Ginsburg, 1969; Bender et al., 1977). Similar results were observed with the N. agilis enzyme (Table 5). The data show that the deadenylylated form was subjected preferentially to a feedback inhibition by alanine, glycine and serine and the adenylylated form by 5 -AMP (Table 5). As the extent of inhibition by these feedback inhibitors was dependent on the degree of adenylylation of the enzyme, which varied slightly from batch to batch $\left(E_{\bar{n}}=9\right.$ to 11$)$, it is not possible to give error limits for the results in Table 5. For various batches of cells the pattern of inhibition was similar to that shown in Table 5, even though the extent of inhibition varied between batches. The SEM within a single batch of cells was never more than $5 \%$.

\section{DISCUSSION}

Glutamine synthetase and glutamate synthase are key enzymes for the assimilation of ammonia in many bacteria grown with low concentrations of ammonia (Tyler, 1978). Glutamate dehydrogenase is usually important when micro-organisms utilize relatively high concentrations of ammonia. As expected, Nitrosomonas europaea grown with $\mathbf{N H}_{4}^{+}$contains glutamate dehydrogenase as the major enzyme for ammonia assimilation (Hooper et al., 1967) and has 
Table 5. Effects of some amino acids and 5'-AMP on adenylylated and deadenylylated forms of the purified glutamine synthetase

The deadenylylated form of glutamine synthetase was prepared by SVP treatment as described in Fig. 1 , except that the incubation was for $1 \mathrm{~h}$. The adenylylation state of the enzyme was checked by determining the effect of $\mathrm{Mg}^{2+}$ on transferase activity at $\mathrm{pH} \mathrm{7.4}$ as described in Table 4 . All amino acids were at a final concentration of $10 \mathrm{mM}$ and AMP at $20 \mathrm{mM}$. The activities of untreated (GS-AMP) and SVP-treated (GS) enzyme were 215 and $190 \mu \mathrm{mol} \gamma$-glutamyl hydroxamate produced $\mathrm{min}^{-1}\left(\mathrm{mg}^{2}\right.$ protein $)^{-1}$, respectively.

$\begin{array}{lcc}\text { Additions } & \overbrace{\text { GS-AMP }}^{\begin{array}{c}\text { Percentage inhibition } \\ \text { of transferase activity }\end{array}} \\ \text { L-Alanine } & 70 & \text { GS } \\ \text { L-Glycine } & 35 & 85 \\ \text { L-Serine } & 40 & 60 \\ \text { 5'-AMP } & 65 & 55 \\ & & 36\end{array}$

relatively little glutamine synthetase activity (Bhandari \& Nicholas, 1981). On the other hand, $N$. agilis, an $\mathrm{NO}_{2}^{-}$oxidizing bacterium, has appreciable activities of glutamine synthetase and glutamate dehydrogenase and little glutamate synthase (Kumar \& Nicholas, 1982).

In this paper it is shown that the enzyme from $N$. agilis has properties similar to those of the enzyme from other bacteria, viz. requirement for divalent cations, molecular weight, number of subunits and inhibition by amino acids and $\mathrm{NH}_{4}^{+}$. The inhibition by $\mathrm{NH}_{4}^{+}$of the transferase activity of glutamine synthetase supports a postulated model that glutamine reacts with the enzyme in such a way that its $-\mathrm{NH}_{2}$ group occupies the $\mathrm{NH}_{4}^{+}$binding site, while the 'oxygen binding' site to which glutamate is normally bound is required for the attachment of the corresponding oxygen group of glutamine (Gass \& Meister, 1970). The results also indicate that the inactivation of the $\mathrm{NH}_{4}^{+}$binding site by glutamine would preclude the binding of $\mathrm{NH}_{2} \mathrm{OH}$ at this locus.

It is of interest that the $N$. agilis enzyme was highly adenylylated even when the cells were grown with nitrite but without any ammonia in the culture medium. CTAB treatment of the cultures prior to harvest had no substantial effect on the state of adenylylation of glutamine synthetase. Relatively low concentrations of CTAB $\left(2 \cdot 5 \mu \mathrm{g} \mathrm{ml}^{-1}\right)$ were used compared to those used for other bacteria (Bender et al., 1977; Davies \& Ormerod, 1982; Michalski et al., 1983) because higher concentrations resulted in cell lysis. This lysis may be associated with the low cell density of exponentially-grown cultures of $N$. agilis.

Cells of $N$. agilis contained approximately $30 \mathrm{~mm}$ intracellular $\mathrm{NH}_{4}^{+}$, assuming that the intracellular water space is about $1.2 \mu \mathrm{l}(\mathrm{mg} \text { dry wt) })^{-1}$ (Kumar \& Nicholas, 1983). This would explain why glutamine synthetase is highly adenylylated so that glutamate dehydrogenase is the main route of $\mathrm{NH}_{4}^{+}$assimilation (Kumar \& Nicholas, 1982, 1984). Ammonia accumulation in cells is possible if nitrite reductase is under minimal regulatory control.

The native adenylylated form of glutamine synthetase could be deadenylylated by SVP. This indicates that the $N$. agilis enzyme is indeed regulated by an adenylylation/deadenylylation mechanism. Another line of evidence to support this conclusion is that differentially adenylylated forms of the enzyme differ in their $\mathrm{pH}$ optima. The isoactivity $\mathrm{pH}$ of 7.4 lies between the value 7.15 for Escherichia coli (Stadtman et al., 1970) and 7.55 for Klebsiella aerogenes (Bender et al., 1977). The isoactivity point of the $N$. agilis enzyme was independent of the purification stage of the enzyme as was also found in $K$. aerogenes (Bender et al., 1977).

S. K. is grateful to the University of Adelaide for a postgraduate scholarship. The project was supported by a grant to D. J. D. N. from the Australian Research Grants Committee. 


\section{REFERENCES}

AleEM, M. I. H. (1970). Oxidation of inorganic nitrogen compounds. Annual Review of Plant Physiology 21, 67-90.

AleEm, M. I. H. (1977). Coupling of energy with electron transfer reactions in chemolithotrophic bacteria. Symposia of the Society for General Microbiology 27, 351-381.

ALEF, K. \& ZUMFT, W. G. (1981). Regulatory properties of glutamine synthetase from the nitrogenfixing phototrophic bacterium Rhodopseudomonas palustris. Naturforschung 36c, 784-789.

Alef, K., Burkhardt, H. J., Horstmann, H. J. \& ZUMFT, W. G. (1981). Molecular characterization of glutamine synthetase from the nitrogen-fixing phototrophic bacterium Rhodopseudomonas palustris. Naturforschung 38c, 246-254.

ANDREws, P. (1970). Estimation of molecular size and molecular weights of biological compounds by gel filtration. Methods in Biochemical Analysis 18, 153.

Ballantine, R. (1957). Determination of total nitrogen and ammonia. Methods in Enzymology 3, 984995.

Bender, R. A., Janseen, K. A., Resnik, A. D., Blumenberg, M., FoOR, F. \& Magasanik, B. (1977). Biochemical parameters of glutamine synthetase from Klebsiella aerogenes. Journal of Bacteriology 129, 1001-1009.

BhaNDARI, B. \& Nicholas, D. J. D. (1979). Ammonia and $\mathrm{O}_{2}$ uptake in relation to proton translocation in cells of Nitrosomonas europaea. Archives of Microbiology 122, 249-255.

BHANDARI, B. \& Nicholas, D. J. D. (1981). Some properties of glutamine synthetase from the nitrifying bacterium Nitrosomonas europaea. Australian Journal of Biological Sciences 34, 527-539.

BRADFORD, M. M. (1976). A rapid and sensitive method of the quantitation of microgram quantities of proteins utilizing the principle of protein dye binding. Analytical Biochemistry 72, 248-254.

Cleland, W. A. (1967). The statistical analysis of enzyme kinetic data. Advances in Enzymology 29, 132.

DARRow, R. A. \& KNoTts, R. R. (1977). Two forms of glutamine synthetase in free-living root nodule bacteria. Biochemical and Biophysical Research Communications 78, 554-559.

Davies, W. \& Ormerod, J. G. (1982). Glutamine synthetase in Chlorobium limicola and Rhodospirillum rubrum. FEMS Microbiology Letters 13, 75-78.

GASS, J. D. \& MEISTER, A. (1970). Computer analysis of active site of glutamine synthetase. Biochemistry $\mathbf{9}$, 1380-1389.

GinsBurg, A. (1969). Conformational changes in glutamine synthetase from Escherichia coli. II. Some characteristics of the equilibrium binding of feedback inhibitors to the enzyme. Biochemistry 8,1726 1740 .

Ginsburg, A. \& Stadtman, E. R. (1973). Regulation of glutamine synthetase in Escherichia coli. In The Enzymes of Glutamine Metabolism, pp. 9-43. Edited by S. Prusiner \& E. R. Stadtman. New York: Academic Press.

HoOper, A. B., Hansen, J. \& Bell, R. (1967).
Characterization of glutamate dehydrogenase from the ammonia oxidising chemoautotroph Nitrosomonas europaea. Journal of Biological Chemistry 242, 288-296.

Hubbard, J. S. \& Stadtman, E. R. (1967). Regulation of glutamine synthetase. II. Patterns of feed back inhibition in microorganisms. Journal of Bacteriology 93, $1045-1055$

Johansson, B. C. \& GEST, H. (1977). Adenylylation/ deadenylylation control of the glutamine synthetase of Rhodopseudomonas capsulata. European Journal of Biochemistry 81, 365-371.

KELLY, D. P. (1971). Autotrophy; concepts of lithotrophic bacteria and their organic metabolism. Annual Review of Microbiology 25, 177-210.

KhanNa, S. \& Nicholas, D. J. D. (1983). Some properties of glutamine synthetase and glutamate synthase from Chlorobium vibrioforme $\mathrm{f}$. thiosulfatophilum. Archives of Microbiology 134, 98-103.

KINGDON, H. S. \& STADTMAN, E. R. (1967). Regulation of glutamine synthetase. X. Effect of growth conditions on the suceptibility of Escherichia coli glutamine synthetase to feed back inhibition. Journal of Bacteriology 94, 949-957.

Kumar, S. \& Nicholas, D. J. D. (1981). Oxygendependent nitrite uptake and nitrate production by cells, spheroplasts and membrane vesicles of Nitrobacter agilis. FEMS Microbiology Letters 11, 201206.

Kumar, S. \& Nicholas, D. J. D. (1982). Assimilation of inorganic nitrogen compounds by Nitrobacter agilis. Journal of General Microbiology 128, 17951801.

KumaR, S. \& Nicholas, D. J. D. (1983). Proton electrochemical gradients in washed cells of Nitrosomonas europaea and Nitrobacter agilis. Journal of Bacteriology 154, 56-71.

Kumar, S. \& Nicholas, D. J. D. (1984). NAD ${ }^{+}$- and $\mathrm{NADP}^{+}$-dependent glutamate dehydrogenases in Nitrobacter agilis. Journal of General Microbiology 130, 967-973.

LAEMMLI, U. K. (1970). Cleavage of structural proteins during the assembly of the head of bacteriophage T4. Nature, London 227, 680-685.

Magasanik, B., Prival, M. J., Brenchley, J. E., Tyler, B. M., Deleo, A. B., Stereicher, S. L., Bender, R. A. \& Paris, C. G. (1974). Glutamine synthetase as a regulator of enzyme synthesis. In Current Topics in Cellular Regulation, vol. 8, pp. 119138. Edited by B. L. Horecker \& E. R. Stadtman. New York: Academic Press.

Meister, A. (1974). Glutamine synthetase of mammals. In The Enzymes, vol. 10, pp. 699-754. Edited by P. D. Boyer. New York: Academic Press.

Michalski, W. P., Nicholas, D. J. D. \& Vignais, P. M. (1983). ${ }^{14} \mathrm{C}$-labelling of glutamine synthetase and Fe protein of nitrogenase in toluene-treated cells of Rhodopseudomonas capsulata. Biochimica et biophysica acta 743, 136-148.

Murrell, J. C. \& Dalton, H. (1983). Purification and properties of glutamine synthetase from Methylococcus capsulatus (Bath). Journal of General Microbiology 129, 1187-1196.

Nicholas, D. J. D. (1963). The metabolism of 
inorganic nitrogen and its compounds in microorganisms. Biological Reviews 38, 530-568.

Nicholas, D. J. D. (1978). Intermediary metabolism of nitrifying bacteria, with particular reference to nitrogen, carbon and sulfur compounds. In Microbio$\log y-1978$, pp. 305-309. Edited by D. Schlessinger. Washington, DC: American Society for Microbiology.

Siedel, J. \& Shelton, E. (1979). Purification and properties of Azotobacter vinelandii glutamine synthetase. Archives of Biochemistry and Biophysics 192, 214-224.

Shapiro, B. M. \& Stadtman, E. R. (1970). Glutamine synthetase (Escherichia coli). Methods in Enzymology 17A, 910-922.

Stadtman, E. R., Ginsburg, A., Ciardi, J. E., Yeh, J., Hennig, S. B. \& Shapiro, B. M. (1970). Multiple molecular forms of glutamine synthetase produced by enzyme-catalysed adenylylation and deadenylylation reactions. Advances in Enzyme Regulation 8, 99 118

Stadtman, E. R., Shapiro, B. M., Kingdon, H. S., Woolfolk, C. A. \& Hubbard, J. S. (1968). Cellular regulation of glutamine synthetase activity in Escherichia coli. Advances in Enzyme Regulation 6, 257-289.

SUZUKI, I. (1974). Mechanisms of inorganic oxidation and energy coupling. Annual Review of Microbiology 28, 85-102.
TYLER, B. (1978). Regulation of the assimilation of nitrogen compounds. Annual Review of Biochemistry 47, 1127-1152.

Wallace, W. \& Nicholas, D. J. D. (1969). The biochemistry of nitrifying micro-organisms. Biological Reviews 44, 359-391.

Wallace, W., Knowles, S. E. \& Nicholas, D. J. D. (1969). Intermediary metabolism of carbon compounds by nitrifying bacteria. Archiv für Mikrobiologie 70, 26-42.

Weber, K. \& Osborn, M. (1975). Proteins and sodium dodecylsulfate: molecular weight determination on polyacrylamide gels and related procedures. In The Proteins, 3rd edn, vol. 3, pp. 179-233. Edited by $\mathrm{H}$. Neurath, R. L. Hill \& C. Boeder. New York: Academic Press.

Wohlhueter, R. M., Schutt, M. \& Holzer, H. (1973). Regulation of glutamine synthetase in vivo in E. coli. In The Enzymes of Glutamine Metabolism, pp. 45-64. Edited by S. Prusiner \& E. R. Stadtman. New York: Academic Press.

Woolfolk, C. A., Shapiro, B. M. \& Stadtman, E. R. (1966). Regulation of glutamine synthetase. I. Purification and properties of glutamine synthetase from Escherichia coli. Archives of Biochemistry and Biophysics 116, 177-192. 